PRZEGLĄD NAUK HISTORYCZNYCH 2020, R. XIX, NR 1

http://dx.doi.org/10.18778/1644-857X.19.01.10

\title{
Kościół parafialny w Węgleszynie w świetle relacji z końca XIX stulecia
}

Streszczenie. Krytyczna edycja źródłowa dotyczy odnalezionego w Archiwum Diecezjalnym w Kielcach opisu kościoła parafialnego pw. św. Andrzeja Apostoła w Węgleszynie (woj. świętokrzyskie). Dokument ten został sporządzony na polecenie konsystorza kieleckiego, najpewniej w latach dziewięćdziesiątych XIX w., przez miejscowego proboszcza, księdza Pawła Jędrychowskiego. Jest on o tyle cenny, że zawiera wiele istotnych informacji na temat światyni parafialnej, pomijanych dotychczas w opracowaniach, jak również nieistniejących dziś zabytków, utraconych bezpowrotnie na poczatku ubiegłego stulecia (gotycki dzwon, ambona o rzadkiej formie jabłka, dekoracje ścienne). Edycja tekstu źródłowego poprzedzona została częścią wstępną, w której przedstawiono pokrótce dzieje parafii i wsi Węgleszyn, omówiono wygląd zewnętrzny i wewnętrzny świątyni, jej wystrój i wyposażenie.

Słowa kluczowe: Węgleszyn, kościół parafialny, edycja źródłowa, XIX wiek.

\section{Rys historyczny}

$\mathrm{P}$ oczątki parafii Węgleszyn (woj. świętokrzyskie) tona w mrokach dziejów, toteż do dziś nie doczekały się gruntownego opracowania. Nie zachował się akt erekcji kościoła, nie wiemy zatem, kiedy i z czyjej inicjatywy parafia ta powstała. W 1367 r. pierwotna światynia drewniana została zastapiona murowana, wzniesiona w stylu gotyckim przez biskupa krakowskiego Floriana Mokrskiego (ok. 1305-1380). Nosiła wezwanie św. Andrzeja

* Wydział Filozoficzno-Historyczny, Instytut Historii, Katedra Historii Nowożytnej, e-mail: malgorzata.karkocha@uni.lodz.pl 
Apostoła, a prawo prezenty przysługiwało kolejno dziedzicom Węgleszyna i pobliskiego Zakrzowa ${ }^{1}$. Położona na terenie archidiakonatu kurzelowskiego archidiecezji gnieźnieńskiej parafia węgleszyńska na początku XVI w. składała się z pięciu wiosek (Węgleszyn, Rembiechowa, Kanice, Zakrzów i Tyniec). Dziesięcina $z$ ról folwarcznych i kmiecych w Węgleszynie przynależała do miejscowego plebana, a $z$ Rembiechowej do plebana węgleszyńskiego i prebendarza $z$ Mokrska². Dzięki badaniom księdza Jana Wiśniowskiego można wskazać nazwiska kilku księży administrujących omawianym beneficjum $\mathrm{w}$ czasach staropolskich $z$ data/datami sprawowania przez nich funkcji. Sa to: Jan $z$ Bogucic (wzmiankowany w 1471 r.), kanonik chełmiński i oficjał kurzelowski; Maciej z Kurzelowa (1521); Tomasz Kołaczkowski (1634), który poczynił zapis na rzecz mansjonarzy w Małogoszczu; Tomasz Dembiński (1691, 1736), prepozyt kurzelowski; Grzegorz Nowiński (wikariusz); Walenty Czechowski (1752) oraz Stanisław Bonawentura Sadowski (1761, 1784), dziekan małogoski ${ }^{3}$.

Siedziba parafii - wieś Węgleszyn w XIV w. należała do rodu Jelitczyków, pieczętujących się herbem Jelita albo Koźle Rogi. $\mathrm{W}$ połowie następnego stulecia dobra węgleszyńskie, składajace się w tym czasie $z$ trzech wsi: Węgleszyn, Węgleszyn Mały i Rembiechowa, przeszły droga kupna czy też wiana w ręce możnego rodu Oleśnickich herbu Dębno ${ }^{4}$. Początkowo stanowiły własność Jana Głowacza Oleśnickiego (ok. 1400-1460), wojewody sandomierskiego, brata biskupa krakowskiego Zbigniewa (1389-1455), po nim przeszły w spadku na jego synów i wnuków ${ }^{5}$. W roku 1588 Jan

1 J. Wiśniewski, Historyczny opis kościołów, miast, zabytków i pamiatek $w$ Jędrzejowskiem, Marjówka 1930 (reprint: Kielce 2000), s. 367; Wegleszyn, [w:] Słownik geograficzny Królestwa Polskiego i innych krajów słowiańskich, red. B. Chlebowski, nakł. F. Sulimierskiego i W. Walewskiego, t. XIII, Warszawa 1893, s. 252; M. Rawita-Witanowski, Dawny powiat chęciński, z ilustracjami prof. J. Olszewskiego, oprac. D. Kalina, Kielce 2001, s. 304-305.

2 J. Pielas, W sąsiedzkim kręgu Mikołaja Reja. Dzieje klucza węgleszyńskiego w XVI wieku, [w:] Mikołaj Rej z Nagłowic. W pięćsetna rocznice urodzin, red. W. Kowalski, Kielce 2005, s. 183.

${ }^{3}$ J. Wiśniewski, op. cit., s. 367, 371.

${ }^{4}$ Doskonała monografia tego rodu por. J. Pielas, Oleśniccy herbu Dębno w XVI-XVII wieku. Studium z dziejów zamożnej szlachty doby nowożytnej, Kielce 2007.

${ }^{5}$ Kolejnych przedstawicieli rodu Oleśnickich, posiadaczy klucza węgleszyńskiego, wymienia: id e m, W sasiedzkim kręgu Mikołaja Reja..., s. 181-187, 192-194. Por. też id e m, Oleśniccy herbu Dębno..., s. 59-60 i n. 
Oleśnicki (zm. 1619) nabył od Kacpra Trojanowskiego części wsi Zakrzów, Zalesie oraz Czekny, czym powiększył majętność węgleszyńską. Po śmierci Jana kluczem tym gospodarowała, mająca na nim zapis dożywocia, Izabela $z$ Sędziejowic Chycka (zm. między 1625 a 1629), wdowa po Janie. Potem w drodze podziału przejęła je Zofia $z$ Oleśnickich Straszowa (zm. po 9 II 1636), średnia córka Jana i Izabeli, i przekazała w ręce Straszów. Ci zaś, nie będąc zainteresowani gospodarowaniem w dobrach węgleszyńskich, w 1630 r. sprzedali je urodzonemu Feliksowi Majowi (zm. 1634). W rękach Majów Węgleszyn znajdował się co najmniej do lat siedemdziesiątych XVII w., po czym droga wiana przeszedł do zadłużonej i możnej rodziny Bystrzonowskich herbu Stary Koń, którzy władali wsią niemal do końca XIX stulecia ${ }^{6}$.

Co się tyczy kościoła parafialnego, to jego losy aż do XIX w. nie sa znane ze względu na ubóstwo dokumentacji źródłowej. Pierwszy zachowany inwentarz parafii z $1840 \mathrm{r}$. podaje, że świątynia znajdowała się w złym stanie technicznym: brakowało pokrycia dachu, ściany popękały, a sklepienie groziło zawaleniem. Niedługo potem przeprowadzona została restauracja, w czasie której ściany i sklepienie ściagnięto żelaznymi ankrami, co uchroniło budynek przed kompletna ruina. Przy nawie od strony południowej w miejsce drewnianej kruchty wybudowano murowaną. Wystawiono też nowa dzwonnicę (poprzednia, drewniana, uległa zniszczeniu w wyniku starości i została rozebrana około 1840 r.), a plac kościelny otoczono murem. W latach 1892-1893 staraniem miejscowego proboszcza, księdza Pawła Jędrychowskiego (1855-1906), kościół został rozbudowany, a jego wnętrze odnowione ${ }^{7}$. Przedłużono wówczas nawę od strony zachodniej, a od wschodu, za wielkim ołtarzem, wzniesiono zakrystię na planie prostokąta (dawna, przylegająca do prezbiterium od północy, została zamieniona na skarbczyk). Odświeżono freski w nawie i prezbiterium i pokryto

${ }^{6}$ J. Pielas, W sasiedzkim kręgu Mikołaja Reja..., s. 194-195; id e m, Oleśniccy herbu Dębno..., s. 214, 316-319; W. Kow alski, Struktura społeczna szlachty $i$ struktura własności $w$ powiecie chęcinskim $w$ sześćdziesiątych latach XVII wieku, [w:] Stefan Czarniecki. Żołnierz-obywatel-polityk, red. idem, Kielce 1999, s. 150; S. Borkiewicz, Z. Linowski, Monografia historyczna i gospodarcza powiatu jędrzejowskiego, Kielce 1937, s. 208.

7 Michał Rawita-Witanowski (op. cit., s. 306) błędnie datuje tę przebudowę na 1872 r., a Katalog zabytków sztuki w Polsce, t. III (Województwo kieleckie), red. J.Z. Łoziński, B. Wolff, z. 3 (Powiat jędrzejowski), oprac. T. Przypkowski, Warszawa 1957 [dalej: Katalog zabytków], s. 40 na pierwszą połowę XIX w. 
podobnymi malowidłami dobudowaną część świątyni, aby nadać jej jednolity charakter. Odmalowano i wyzłocono wszystkie ołtarze, jak również zbudowano nowy chór. Ostatnia większa przebudowa nastapiła w 1915 r., gdy pierwotne gotyckie sklepienia łukowe $\mathrm{w}$ nawie zastapiono kolebkowym $\mathrm{z}$ lunetami ${ }^{8}$.

\section{Architektura i wystrój świątyni}

Kościół w Węgleszynie jest orientowany, jednonawowy, z krótkim, prostokątnym prezbiterium, niższym od nawy. Od strony północnej do prezbiterium przylega pierwotna gotycka zakrystia, pełniaca dziś funkcję skarbczyka, od wschodu nowsza z końca XIX w., a do nawy od południa obszerna kruchta, zamknięta półkoliście. Zewnętrzne ściany nawy i prezbiterium opięte sa uskokowymi szkarpami. Fasadę z 1892 r. ujmuja na narożach zdwojone pilastry, na osi znajduje się prosty w formie, wysoki portal zwieńczony trójkątnym frontonem, a w ścianie szczytowej wazony i żelazny krzyż na cokołach. Dachy nad nawa i kruchta sa dwuspadowe, nad prezbiterium i zakrystia trójpołaciowe, a nad skarbczykiem pulpitowy - wszystkie obite blachą. Nad nawa, na wysokości 2/3 kalenicy, mieści się sześcioboczna wieżyczka-sygnaturka zwieńczona krzyżem. Wnętrze o niskim sklepieniu jest jasne, oświetlone prostokatnymi oknami, $z$ których osiem rozmieszczono $\mathrm{w}$ nawie, symetrycznie na każdym boku, jedno w prezbiterium od południa, dwa w nowej zakrystii oraz po jednym w skarbczyku i kruchcie. Ponadto w ścianie szczytowej elewacji zachodniej znajduje się niewielki okulus. Wejście główne usytuowane jest od zachodu, boczne - w kruchcie i nowej zakrystii ${ }^{9}$.

Wyposażenie kościoła stanowią: ołtarz główny i dwa boczne, ambona, kamienne chrzcielnice (gotycka z 1367 r. i barokowa), konfesjonał, ławki, organy oraz stacje drogi krzyżowej. Ołtarze i ambona sa rokokowe, polichromowane na zielono ze złotymi zdobieniami, wykonane około 1700 r. W ołtarzu głównym mieści się łaskami słynący obraz Matki Boskiej z Dzieciątkiem, w bocznych wizerunki Chrystusa Ukrzyżowanego i św. Andrzeja Apostoła. Na ścianach zawieszone sa marmurowe epitafia z XVII-XX w., upa-

8 J. Wiśniewski, op. cit., s. 367-368; M. Rawita-Witanowski, op. cit., s. 306-307; oraz [ks. P. Jędrychowski], Opis kościoła w Węgleszynach, Archiwum Diecezjalne w Kielcach [dalej: ADK], Akta konsystorskie. Opis kościołów dekanatu jędrzejowskiego 1884-1898, sygn. OD-8/3, k. 152-152v.

${ }^{9}$ J. Wiśniewski, op. cit., s. 368; Katalog zabytków, s. 40. 
miętniające miejscowych dziedziców i dobrodziejów. Świątynia - pierwotnie ozdobiona bogatymi freskami o motywach figuralnych i ornamentalnych - dziś pozbawiona jest całkowicie dekoracji ściennych ${ }^{10}$.

\section{Podstawa źródłowa}

Przedstawione do edycji źródło przechowywane jest w Archiwum Diecezjalnym w Kielcach, w teczce Akta konsystorskie. Opis kościołów dekanatu jędrzejowskiego 1884-1898, opatrzonej sygnatura OD-8/3 ${ }^{11}$. Dokument jest niedatowany, wiadomo jednak, że powstał na polecenie konsystorza diecezji kieleckiej z 27 stycznia 1884 r. (№ 210) ${ }^{12}$. Sporządził go, najpewniej w ostatniej dekadzie XIX stulecia ${ }^{13}$, ówczesny proboszcz parafii w Węgleszynie - ksiądz Paweł Jędrychowski ${ }^{14}$. Relacja została spisana w języku polskim na kartkach formatu zbliżonego do A4, zapisanych obustronnie, ponumerowanych od 1 do 4, oznaczonych współcześnie jako karty 152-155. Pismo jest czytelne, kursywne, pod koniec nieco mniej staranne (wynik pośpiechu lub zmęczenia skryby), a w tekście dokonano nielicznych skreśleń i poprawek. Dokument ten, o ile mi wiadomo, nie był dotychczas publikowany.

${ }^{10}$ J. Wiśniewski, op. cit., s. 368; [ks. P. Jędrychowski], Opis kościoła w Węgleszynach..., k. 153-153v.

${ }^{11}$ Pozostałe opisy (w liczbie 21) dotyczą świątyń parafialnych w Brzegach, Chomentowie, Ciernie, Jędrzejowie, Kozłowie, Krzcięcicach, Łukowej, Mieronicach, Mierzwinie, Mnichowie, Mokrsku, Nagłowicach, Nawarzycach, Oksie, Piotrkowicach, Rakoszynie, Sędziszowie, Sobkowie, Tarnawie, Wodzisławiu i Wrocieryżu. Niektóre $z$ nich, m.in. kościołów w Chomentowie, Mierzwinie, Krzcięciach i Nawarzycach, sa niezwykle obszerne, kilkudziesięciostronicowe, inne (np. kościoła w Miechowie) zaledwie kilkustronicowe, choć bywają i krótsze, dwu- i trzystronicowe (Oksa, Sobków). Autorka planuje sukcesywna publikację tych materiałów.

12 Administrator parafii Rakoszyn do Prześwietnego Jeneralnego Konsystorza Diecezji Kieleckiej, 24 XII 1885, ADK, Akta konsystorskie. Opis kościołów dekanatu jędrzejowskiego 1884-1898, sygn. OD-8/3, k. 139.

${ }_{13}$ W źródle wspomniano o rozbudowie i restauracji kościoła w latach 18921893.

${ }^{14}$ Paweł Jędrychowski (1855-1906) - urodzony w Słomnikach 21 I 1855 r., syn Michała i Jadwigi, święcenia kapłańskie otrzymał w 1877 r. W kościele parafialnym w Brzegach znajduje się epitafium $z$ fotografią upamiętniające tego duchownego. Treść inskrypcji podaje J. Wiś niew ski, op. cit., s. 369. W tym samym opracowaniu, na stronie 371, duchowny ten został błędnie odnotowany jako Józef Jędrychowski. Informacje biograficzne o P. Jędrychowskim: ADK, Akta personalia konsystorskie i kurialne. Status cleri 1876-1938, sygn. OP-X/14, k. 88v-89. 
W źródle omówiono dzieje kościoła, jego remonty i przebudowy w XIX stuleciu, opisano architekturę zewnętrzną i wewnętrzną, wystrój i wyposażenie, marmurowe pomniki i epitafia, dzwony, wyszczególniono wreszcie paramenty liturgiczne. Główną zaletą tego dokumentu jest - jak sądzę - opisanie nieistniejących dziś, wysokiej klasy zabytków, utraconych bezpowrotnie w pierwszej połowie ubiegłego stulecia: gotyckiego dzwonu, zarekwirowanego przez austriackie władze okupacyjne w 1915 r., ambony o rzadkiej formie jabłka czy też globu, dekorowanej historia pierwszych rodziców $^{15}$, oraz malowideł ściennych, zniszczonych podczas zakładania nowego sklepienia (1915). Relacja księdza P. Jędrychowskiego pozwala również ustalić dokładny czas rozbudowy kościoła i wystawienia elewacji zachodniej (1892). Wada przekazu jest natomiast słaba orientacja jego twórcy w dziedzinie historii sztuki, przejawiająca się w nieznajomości podstawowych nieraz pojęć $z$ tego zakresu i niefachowym opisie zachowanych obiektów, jak również w dziedzinie epigrafiki. Odczyty napisów nagrobnych, a zapewne także nadzwonnych, dalekie sa bowiem od poprawności: oddano je niejednokrotnie bez uwzględnienia wielkich liter, zaznaczenia końca wiersza czy abrewiacji, a ponadto uzupełniono o znaki diakrytyczne i interpunkcyjne, których próżno szukać w oryginale. Jednak mimo swych niedostatków źródło to dostarcza nam wielu cennych, pomijanych dotychczas w opracowaniach informacji, wzbogacajacc naszą wiedzę o parafii i kościele w Węgleszynie.

\section{Metoda wydawnicza}

Edytowany dokumentu opracowano zgodnie $z$ zaleceniami instrukcji wydawniczej Kazimierza Lepszego ${ }^{16}, z$ pewnymi jednak modyfikacjami. Stosownie do dominujaccej ostatnio w tego typu wydawnictwach tendencji, zachowano charakterystyczne dla języka staropolskiego końcówki: -em, -emi. Bez zmian pozostawiono też ortografię imion i nazwisk (np. Floryan, Krzelcicky). Poprawiono interpunkcję, uzupełniając zdania o przecinki bądź rezygnując $z$ nich w miejscach, gdzie nie było to wymagane. Samogłoski „i”, „y" oraz spółgłoskę „j” oddano zgodnie $z$ aktualnie obowiązującymi

15 Zabytek ten znany jest także $z$ innych opisów (J. Wiśniewski, op. cit., s. 370; M. Rawita-Wita nowski, op. cit., s. 307) i dokumentacji fotograficznej: https://kielce.fotopolska.eu/973292,foto.html (dostęp: 12 II 2020).

${ }^{16}$ Instrukcja wydawnicza dla źródeł historycznych od XVI do połowy XIX wieku, red. K. Lepszy, Wrocław 1953. 
zasadami. W przypadku, gdy litera „y” oznaczała dwie głoski, oddano to zgodnie $z$ wymowa, np. „monstrancya” przez "monstrancyja”. Podwojone głoski „ll” i „pp” zastapiono pojedynczymi, np. w słowach „kollegiata”, „gruppa”. Również zgodnie $z$ obecną praktyka użyto wielkich liter. Powyższe uwagi nie dotyczą inskrypcji nadzwonnych i epitafiów, te bowiem zdecydowano się pozostawić bez zmian. W nawiasach kwadratowych ujęto początek danej strony w oryginale, rozwiązano skróty, a także uzupełniono opuszczone przez pisarza litery. W przypisach tekstowych zamieszczono uwagi odnoszące się do postaci zewnętrznej i brzmienia podstawy źródłowej oraz lekcje wattpliwe, w rzeczowych - objaśniono wymienione w dokumencie osoby i trudniejsze terminy. W źródle występuja następujące abrewiacje: D.O.M. - Deo Optiomo Maximo, św. - święty/ego, X. - Ksiądz.

\section{TEKST ŹRÓDLOWY}

Or.: Archiwum Diecezjalne w Kielcach, Akta konsystorskie. Opis kościołów dekanatu jędrzejowskiego 1884-1898, sygn. OD-8/3, k. 152-155v.

[k. 152] Opis kościoła w Węgleszynie ${ }^{17}$

Kościół w Węgleszynie pod wezwaniem św. Andrzeja Apostoła został wymurowany z cegły około roku 1367 przez X. Floryana Mokrskiego ${ }^{18}$, biskupa krakowskiego. Opis inwentarza parafii Węgleszyn sporządzony w r[oku] 1840 wzmiankuje, że akt erekcji kościoła węgleszyńskiego znajduje się w archiwum kolegiaty kurzelowskiej, a kopie jego przechowuje się na plebanii w Węgleszynie. Dziś jednak ani kopie tego aktu w Wegleszynie, ani też samego oryginału w Kurzelowie ${ }^{19}$ odnaleźć nie można. Historia kościoła

${ }_{17}$ Węgleszyn - wieś w dawnym woj. sandomierskim, w pow. chęcińskim, $10 \mathrm{~km}$ na południowy zachód od Małogoszcza, nad rzeką Lipnicą.

${ }_{18}$ Florian Mokrski h. Jelita (ok. 1305-1380) - biskup krakowski w latach 1367-1380. Por. K.R. Prokop, Poczet biskupów krakowskich, Kraków 1999, s. 64-67.

19 Kurzelów - dawne miasto (do 1869), obecnie wieś w pow. włoszczowskim. W czasach staropolskich siedziba archidiakonatu. 
węgleszyńskiego, jego losy aż do roku 1840 nie sa nam znane; nie wiadomo też, kiedy i przez kogo kościół ten był konsekrowanym. Pierwszy i jedyny, jak dotąd, dokument, który nam dzieje przedstawia, jest wyżej zacytowany „Opis inwentarza parafii Węgleszyn”, sporządzony w $1840 \mathrm{r}[\mathrm{oku}]$. Z tego źródła dowiadujemy się, iż przed rok[iem] 1840 wskutek niedbalstwa parafian kościół węgleszyński stał przez długi czas niepokryty, woda zaciekała i wskutek tego zrujnowały się mury, sklepienie pękło i nieco się opuściło. Jakich użyto środków do poprawienia kościoła i co zrobiono - nie wiemy; wiemy tylko, że środki te były niewystarczające, bo sklepienie coraz bardziej się osuwało, $[a]$ osuwajac się, napierało na ściany i groziło upadkiem i całkowita ruina kościoła. Aby ciagłemu, stopniowemu osuwaniu się sklepienia zapobiec, użyto środka odpowiedniego - kazano ściagnąc ściany i sklepienie kilku żelaznymi ankrami i w ten sposób uchroniono kościół od ruiny. Oprócz tego zrobiono następujace poprawki: wybudowano od strony południowej piękna murowana dzwonnice, pokryta blacha, której wcale nie było. Ongis ${ }^{a}$, przed r[okiem] 1840, była tu dzwonnica drewniana, zbudowana na kształt wieży przed głównemi drzwiami kościoła, ale już w r $[o k u] 1840[k .152 v]$ zupełnie spróchniała i upadła. Także ze strony południowej przybudowano obszerna murowana kruchtę, krytą blacha, w tem samem miejscu, gdzie dawniej, jak widać $z$ opisu inwentarza, znajdowała się kruchta drewniana. Nadto otoczono murem obszerny cmentarz kościelny; w murze od strony wschodniej, przy drodze prowadzącej do wsi, umieszczono dużą bramę żelazną i dwie mniejsze, podobneż furtki; od strony południowej umieszczono trzecia furtkę. W tym samym czasie zastapiono dawną nietrwała posadzkę $z$ białego kamienia - inna trwalszą.

W naszych czasach wskutek parcelacji majątku Węgleszyn i przyległych do niego folwarków liczba ludności w tutejszej parafii znacznie się powiększyła i kościół miejscowy, mający tylko 30 łokci długości (prezbiterium 10, nawa 20) i 12 szerokości (prezbiterium 7, nawa 12), [.] $]^{\mathrm{b}}$ okazał się stanowczo za szczupłym do pomieszczenia wszystkich, pragnacych brać udział w nabożeństwie; trzeba było koniecznie temu zaradzić. W roku przeto 1892, po przeprowadzeniu niezbędnych formalności i uchwaleniu potrzebnych składek, rozpoczęto zamierzone dzieło. Mianowicie: a) rozebrano tylna ścianę kościoła i przedłużono nawę kościelną o 18 łokci światła; b) ponie-

${ }^{a}$ Odczyt jedynie prawdopodobny.

b Słowo skreślone. 
waż zakrystyjka, umieszczona $z$ boku prezbiterium od strony pó1nocnej, była zbyt mała, niską i ciemna, a rozszerzyć jej ze względów techniczny i aby nie zasłonić jednego okna w nawie kościelnej nie było można, przeto wybudowano nowa, obszerną zakrystię w formie półkola od strony wschodniej, to jest [.] ${ }^{\mathrm{c}}$ od frontu kościoła, poza wielkim ołtarzem, a dawną zakrystię obrócono na skarbczyk.

$\mathrm{W}$ następnym $1893 \mathrm{r}[\mathrm{oku}]$ przeprowadzona została restauracja wewnątrz kościoła. Ponieważ wewnętrzny stan starego kościoła na gwałt wymagał odświeżenia, przeto cały kościół: tak nowo dobudowana część, jak też i dawna został odmalowany. Odmalowano na nowo, wyzłocono i oczyszczono wszystkie trzy ołtarze, odświeżono freski, jakiemi był ozdobiony dawniejszy kościół i starano się pokryć i ozdobić nową część kościoła podobnemiż malowidłami, aby cały kościół nosił jednolity charakter i jednakową szatę. Zbudowano wreszcie nowy chór i na tem przerwano roboty około kościoła, odkładając do stosowniejszego czasu uzupełnienie tych braków, jakie jeszcze pozostały, jak np. ufundowanie nowych organów na miejsce obecnych, które już prawie nie [k. 153] mogą służyć do użytku.

d-Wygląd kościoła zewnętrzny ${ }^{-d}$. Na zewnątrz kościół węgleszyński nosi cechy stylu gotyckiego. Jest to gmach wysoki, wysmukły, o szpiczastym szczycie, nakryty wysokim i spadzistym gontowym dachem. Pośrodku dachu wznosi się dosyć wysoka i zgrabna wieżyczka-sygnaturka; prezbiterium jest daleko niższe od nawy. W kościele jest 9 okien: $z$ tych jedno oświeca prezbiterium, a 8 pozostałych nawę. Do głównego dachu przylega kilka przybudówek, a mianowicie: od frontu nowa zakrystia o 2 oknach, $z$ jednego boku od strony północnej dawna mała zakrystyjka o jednym okienku, z drugiego boku od południa dość obszerna kruchta kościelna. Dawniej dwoje tylko drzwi prowadziło do kościoła: drzwi duże, umieszczone w tylnej ścianie kościoła, na wprost wielkiego ołtarza, i drugie mniejsze, prowadzące do kruchty kościelnej. Dzisiaj po przybudowaniu kościoła jest troje drzwi - dwoje dużych, przeciwległych sobie drzwi, umieszczonych od strony południowej i północnej (nie umieszczono dużych drzwi, jak było dawniej, w tylnej ścianie kościoła, aby uniknąć przeciagów) i trzecie mniejsze - dawne, prowadzące do kruchty. Nadto osobne drzwi prowadzą z cmentarza do nowej zakrystii.

\footnotetext{
c Wymazany przecinek.

d-d Fragment zapisany na marginesie.
} 
e-Wygląd wewnętrzny ${ }^{\mathrm{e}}$. Zewnętrzny wygląd kościoła każe się spodziewać, że po wejściu doń ujrzymy wnętrze wysokie o sklepieniu ostrołukowem. Tymczasem jest zupełnie inaczej: kościół wewnątrz jest niski o sklepieniu owalnem. Prawdziwą ozdobę kościoła stanowia trzy piękne i nadzwyczaj gustowne ołtarze $z$ drzewa, kiedyś pomalowane na kolor biało kamienny - dziś purpurowe ze złotem. W wielkim ołtarzu na mensie wysokiej wznosi się wysokie, ozdobnie rzeźbione tabernakulum, pomalowane na kolor srebrny. Mensa $z$ tabernakulum wysuniętą jest naprzód i oddzieloną od pozostałej części ołtarza. $Z$ obydwóch końców mensy wznoszą się dwie złocone kolumny, uwieńczone również złoconemi kapitelami, na kapitelach dwa rzeźbione, biało lakierowane aniołki, jeden $z$ księga, drugi $z$ tablica w ręku. Kapitele łączą się $z$ tylna, przytykająca do ściany częścia [.] $]^{g}$ ołtarza, w której umieszczony jest obraz $\mathrm{N}$ [ajświętszej] Panny Szkaplerznej, malowany na płótnie i okryty srebrna sukienka. Za zasuwę do tego obrazu służy inny obraz malowany na drzewie, przedstawiający św. Annę. Wyżej ponad obrazem grupa przedsta[k. 153v]wiająca Boga Ojca otoczonego aniołami, którzy trzymaja rozmaite insygnia. Dwa boczne mniejsze ołtarze w swym ogólnym charakterze zbliżone są do stylu wielkiego ołtarza. Po prawej stronie znajduje się ołtarz $z$ obrazem Ukrzyżowanego Zbawiciela, malowanym na płótnie. Na tym ołtarzu wiszą: małe srebrne wotum $z$ kula w środku i literami K.B., serce miedziane wyzłacane i relikwiarzyk w złotej koronie. Wyżej mieści się mniejszy obraz św. Michała Archanioła; obok mensy dwa duże posagi świętych biało lakierowane, a na gzemsach ołtarza białe aniołki.

$Z$ drugiej strony nawy mieści się podobnego zupełnie kształtu trzeci obraz św. Andrzeja Apostoła; w górze, nad obrazem św. Andrzeja, [.] ${ }^{\text {h }}$ mniejszy obraz św. Mikołaja, a obok ołtarza białe posagi św. Wojciecha i św. Stanisława Biskupa. Na łuku kończącym prezbiterium ${ }^{20}$ mieści się okragła, w kształcie jabłka, ambona, a na niej obrazy przedstawiające historię pierwszych naszych Rodziców. Sklepienie i ściany kościoła ozdobione sa pięknemi freskami. W prezbiterium na sklepieniu [.] $]^{\mathrm{i}}$ spostrzegamy obraz

\footnotetext{
e-e Tekst na marginesie.

f W oryginale: „wusunięta”.

${ }^{g}$ Dwie litery skreślone.

h Wymazane słowo „obraz”.

i Wyraz skreślony.

${ }^{20}$ Czyli tęczy.
} 
$\mathrm{N}$ [ajświętszej] Panny $\mathrm{z}$ dzieciątkiem Jezus na ręku, podającem szkaplerz klęczącemu niżej świętemu.

$\mathrm{Na}$ ścianie po prawej stronie ołtarza wielki obraz przedstawia Pana Jezusa w Ogrójcu, a obok łuku kończaccego prezbiterium, na jednej i drugiej ścianie, dwa obrazy przedstawiają: Chrzest Pana Jezusa w Jordanie i świadectwo św. Jana o Panu Jezusie. W nawie na sklepieniu widzimy Trójcę Przenajświętszą - po rogach czterej doktorowie Kościoła, a jeszcze dalej cztery jakby postacie symboliczne; w dalszym ciagu na sklepieniu - w nowo zbudowanej części kościoła - widzimy dzieciątko Jezus otoczone aniołami. Na ścianie po lewej stronie, nad bocznemi drzwiami, fresk przedstawia Pana Jezusa wypędzającego kupczących z kościoła, niżej napis: Domus mea - domus orationis ${ }^{21}$; na przeciwległej ścianie dwa obrazy: Kuszenie na puszczy i Przemienienie Pańskie.

W kościele jest kilka pomników: tak w prezbiterium spostrzegamy wmurowaną w ścianę niedużą marmurową tabliczkę, na niej u góry wyryty wizerunek Ukrzyżowanego Zbawiciela, pod krzyżem klęczy niewiasta $z$ trojgiem dzieci, a niżej wiersz, w którym mąż wychwala cnoty zmarłej swej małżonki Katarzyny ${ }^{j}$ Majowej $^{22}$, pochodzacej $z$ [k. 154] Koniecpola. Pomnik pochodzi z XVI wieku. W nawie po prawej stronie widzimy cztery pomniki Bystrzonowskich $^{23}$. Z tych trzy jednakowego kształtu, a czwarty jest to prosta, skromna, $z$ czarnego marmuru niewielka tabliczka; trzy zaś pierwsze $z$ brzegu sa duże i grubsze marmurowe płyty, nad płytami trójkąty marmurowe, na nich symbol śmierci: wąż odcinający zębami od drzewa gałązę $z$ dojrzałym owocem. Na płytach sa herby, a pod nimi napisy. Na przeciwległej ścianie, obok ołtarza św. Andrzeja, jeden jest tylko pomnik w kształcie wielkiej marmurowej płyty, na pomniku u góry Zbawiciel Ukrzyżowany, a niżej napis, trudny już dzisiaj do odcyfrowania. Opiewa on boleść małżonka (Krzelcicky alias Mrożek) z powodu straty żony i syna, zamordowanych przez Szwedów.

j Nadpisane nad wymazanym słowem.

${ }^{21}$ z Mt 21, 13: „Dom mój jest domem modlitwy”.

${ }^{22}$ Katarzyna Majowa (1600-1631) - dziedziczka Węgleszyna, żona Feliksa vel Szczęsnego Maja (por. przyp. 29), który w styczniu 1630 r. zakupił Węgleszyn od Zofii z Oleśnickich Straszowej. Por. J. Pielas, Oleśniccy herbu Dębno..., s. 318; oraz epitafium nr $1 \mathrm{w}$ tekście źródłowym.

${ }^{23}$ O Bystrzonowskich herbu Stary Koń por. A. Boniecki, Herbarz polski, cz. 1 (Wiadomości historyczno-genealogiczne o rodach szlacheckich), t. II, Warszawa 1900, s. 292-294. 
W zakrystii nie ma nic szczególnej godnego uwagi oprócz kilku kawałków czerwonej materyji, pokrytych srebrnym wypukłym haftem; kawałki te stanowia resztki dawnej sukienki $z$ obrazu Najśw[iętszej] Maryi Panny. Ornaty wszystkie sa $z$ nowych czasów i żadnej osobliwości nie zawierają. $Z$ utensyliów kościelnych są tu: duża srebrna pozłacana monstrancyja; trzy kielichy, $z$ tych jeden srebrny $z$ daru Bystrzonowskich ${ }^{24}$; dwa inne, jak się zdaje, nie srebrne, lecz z innego jakiegoś kruszcu - pozłacane, i srebrny krzyż, który też zarazem jest i relikwiarzem.

$\mathrm{Na}$ dzwonnicy są dwa duże miedziane dzwony i trzeci maleńki (sygnaturka), dziś rozbity.

Tak się przedstawia dzisiaj stan parafialnego kościoła w Węgleszynie.

\section{Pomniki}

\section{1. pamiątka}

$$
\text { D.O.M. }
$$

Jey Moscy P.P[any] Katarzynie Majowy ${ }^{25}{ }^{\mathrm{k}-} \mathrm{z}$ Konieczpola ${ }^{-\mathrm{k}} 26$

Ktora urodzieła sie $1690^{27}$ we czwartek po Ś $[$ wietym] Pietrze w okowach ${ }^{28}$ - umarła 15 Marca 1631 (?)

Choć koszczy leżą w ziemi, dusza mieska w niebie Przecie małżonko moja w sercu ja mam Ciebie Dałem czi był to serce jeszcze za żywota [k. 154v] Mam je zaś, ale twoja w nim wiryta cznota Niech że inszy mieszająm proch zmarłych w napoje Besz tego żono moja grób twój serce moje.

k-k Nadpisane nad dwoma skreślonymi słowami.

${ }^{24}$ Datowany na 1748 r., wspomina o nim: J. Wiśniews ki, op. cit., s. 370; Katalog zabytków, s. 40; Corpus inscriptionum Poloniae, t. I (Województwo kieleckie), red. J. Szymański, z. 1, z. 2 (Jędrzejów i region jędrzejowski), wydała, wstępem i komentarzem opatrzyła B. Trelińska, Kielce 1978, nr 1, s. 160-161.

25 Por. przyp. 22.

${ }^{26}$ Koniecpol - miasto w pow. częstochowskim, nad rzeką Pilicą.

${ }^{27}$ Omyłka pisarza, co wynika $z$ treści inskrypcji. Corpus inscriptionum..., nr 180, s. 159 podaje rok 1600.

${ }^{28} \mathrm{Tj} .3$ sierpnia. 
Dałem czi żono wyricz to jest ten nagrobek Którym sprawyl Szczęsny Maj ${ }^{29}$ strapiony małżonek ${ }^{30}$.

Nad tym napisem wyryty krzyż, pod którym klęczą troje chłopców i kobieta - wszyscy ze złożonymi do modlitwy rękami.

Trójkąt, w którym umieszczono portret zmarłego; na wierzchu trójkąta wąż obwinięty koło gałązki $z$ owocem, odgryza ją. Trójkąt wsparty na dwóch kulach na marmurowej płycie, na której stoi urna i krzyżyk - na płycie napis:

\section{D.O.M. (nad napisem koń[)]}

Michałowi Bystrzonowskiemu ${ }^{31}$ Podkomorzemu J[ego] K[rólewskiej] M[oś]ci na wzór Potomności i późna pamiątkę ze przy gruncie Religii i nieposzlakowanej cnocie Obowiązki Obywatela, Bliźniego y Stanu, które on umiał dziwnie połączyć mogą bydź doskonale wypełnione, Wdzięczny Syn ${ }^{32}$ Dobrotliwemu y Ukochanemu Oycu ten Marmur położył. Umarł D[nia] 23. Listopada R[oku] P[ańskiego] 1789. Żyjąc lat 56.

Życz mu Wiecznego spoczynku ${ }^{33}$.

${ }^{29}$ Feliks vel Szczęsny Maj (zm. 1634) - dziedzic wsi Węgleszyn. Był trzykrotnie żonaty: 1) z nieznaną bliżej Balicka, z która miał syna Stanisława, 2) z Katarzyna Koniecpolska, wdowa po Macieju Pukarzewskim, z której pozostawił synów Feliksa i Stefana, 3) z Rawiczówną-Grotkowską. Syn Stanisław wystawił mu marmurowy grobowiec w kościele bernardynów w Krakowie. Por. J. Wiśn niews ki, op. cit., s. 236; M. Rawita-Witanowski, op. cit., s. 307; K. Nies iecki, Herbarz polski, t. VI, wyd. J.N. Bobrowicz, Lipsk 1841, s. 357.

${ }^{30}$ Tekst inskrypcji podają także: J. Wi śn niew ski, op. cit., s. 369; M. Rawita-Witanowski, op. cit., s. 307; Corpus inscriptionum..., nr 180, s. 159.

${ }^{31}$ Michał Bystrzonowski (zm. 1789) - dziedzic dóbr węgleszyńskich, syn Karola, łowczego chęcińskiego, od 1758 r. podkomorzy królewski, żonaty z Katarzyna Srzeniawska Borzysławska, z która miał jedynego syna Kazimierza. Por. A. B oniecki, op. cit., s. 293; M. Rawita-Witanowski, op. cit., s. 309; S. Borkiewicz, Z. Linowski, op. cit., s. 208.

32 Najpewniej Kazimierz Bystrzonowski (zm. 1840), por. pomnik nr 3.

${ }_{33}$ Tekst inskrypcji także w: J. Wiśniewski, op. cit., s. 370; M. Rawita-Witan owski, op. cit., s. 308; oraz Corpus inscriptionum..., nr 185, s. 162-163. 
3. (obok wiszaccy)

Takiego samego kształtu, jak i poprzedni - z podobnym emblematem, inszeń tylko w miejsce portretu, jakiś odcisk $z$ napisem dzisiaj nieczytelnym. ${ }^{1-}$ Marmur koloru brazowego ${ }^{-1}$. Pod herbem napis:

$$
\text { D.O.M. }
$$

Kazimierz z Szafrańców Bystrzonowski ${ }^{34}$ syn Michała i Katarzyny $z$ Borzysławskich uro[dził] się d[nia] 4. Marca 1764 umarł d[nia] 11 Stycznia $1840 \mathrm{r}[\mathrm{oku}$ ] Wielokrotny posel z Wojewodztwa i Powiatu swojego, Reprezentant Województwa Sandomierskiego przy boku Najwyższego Naczelnika ${ }^{35}$. Mą̇̇ ten przejdzie do najpóźniejszej potomności jako wzór w[szel]kich Cnót Obywatelskich. Zostawił w srogim żalu pograżonych Małżonkę Annę z $\mathrm{Hr}[a]$ biów z Brzezic Russockich $^{36}$, syna [k. 155] Ludwika, córki Liberatę i Kamillę ${ }^{37}$. Przechodniu, westchnij za duszę cnotliwego prawego Polaka ${ }^{38}$.

4.

Kształt zupełnie podobny do poprzedniego. W herbie korona $z$ wbitym toporem i lwem niżej - z jednej strony koń, $z$ drugiej lew.

$$
\text { D.O.M. }
$$

Anna $z$ Hrabiów Rzym[skich] De Breze Russockich, małżonka Kazimierza $z$ Szafrańców Bystrzonowskiego była aż do skonu swojego żywym obrazem prawdziwej Chrześcianki była albowiem dobra

1-1 Fragment podkreślony.

${ }^{34}$ O Kazimierzu Bystrzonowskim (zm. 1840), właścicielu majętności Węgleszyn, Bebelno, Dąbie i Boczkowice, por. A. Boniecki, op. cit., s. 294; M. Rawita-Witanowski, op. cit., s. 309; S. Borkiewicz, Z. Linowski, op. cit., s. 208.

35 Tadeusza Kościuszki.

${ }^{36}$ Anna $z$ Russockich Bystrzonowska (zm. 1844), odnotowana przez A. Bonieckiego, op. cit., s. 294. Por. pomnik nr 4.

${ }_{37}$ O Ludwiku, Liberii i Kamilli, dzieciach Kazimierza Bystrzonowskiego i Anny z Rusockich por. S. Borkiewicz, Z. Linowski, op. cit., s. 208.

${ }^{38}$ Epitafium to wzmiankuje M. Rawita-Witanowski, op. cit., s. 308. 
Polką, Obywatelką, Czułą Córką, tkliwą Małżonką, Najlepszą Matką, Pobożna i Miłosierna Matroną.

Najpowinniejszą wdzięcznością przejęte Dzieci polecają Pamięć Swojej Matki Karmicielki Gorącym Modlitwom Pobożnych.

Zgasła 4 Lutego 1844 r[oku] Życia 66 $6^{39}$.

5.

Mała czarna marmurowa tabliczka, wmurowana w ścianę.

\author{
D.O.M. \\ Współ Bracie Polaku! \\ Westchnij za duszę \\ Salezego Bystrzonowskiego ${ }^{40}$ \\ Który w obronie Twoiey Wolności \\ Poległ D[nia] 5. Czerwca 1794 r[oku] \\ Pod Naczelnictwem \\ Tadeusza Kościuszki ${ }^{41}$
}

${ }^{\mathrm{m}} \mathrm{Z}$ lewej strony kościoła ${ }^{-\mathrm{m}}$

Duża marmurowa płyta, wmurowana w ścianę. Na wierzchn[i] ej części płyty wyryty Pan Jezus na krzyżu; z lewej strony krzyża klęczy niewiasta, poza nią herb już zatarty, nad herbem duże litery i A.K.M. - pod herbem: Z.P. Z drugiej strony krzyża klęczy rycerz uzbrojony, a poza nim jesz[cz]e jakaś postać męska - dalej herb, nad którym znów litery: M.K.M.; pod herbem litery: Z.K. Napis: [k. 155v]

$\mathrm{m}-\mathrm{m}$ Zapisane na marginesie.

39 Por. M. Rawita-Witanowski, op. cit., s. 309.

40 Salezy Bystrzynowski (zm. 1794) - syn Kajetana, kasztelana małogoskiego, uczestnik insurekcji kościuszkowskiej. Poległ w bitwie pod Szczekocinami 5 VI 1794 r. Por. A. Boniecki, op. cit., s. 293.

${ }^{41}$ Tekst inskrypcji także w: J. Wi śn niewski, op. cit., s. 369; Corpus inscriptionum..., nr 184, s. 161-162. 
D.O.M.

In Epitaphium G[enerosae] Annae ${ }^{42}$ De Polanowicze ${ }^{43}$

Consortis L[egi] timae atq[ue] Charissime Olim G[enerosi] Stanislai Krzelcicky

Dicti Mrożek ${ }^{44}$ De Krzelc ${ }^{\text {icze }}{ }^{45}$. Et Fily Eorum Amantissimi G[enerosi] Martini Krzelcicky ${ }^{46}$ De Eadem Krzelcicz ${ }^{\mathrm{m}}$ e.

1) Tym Parka Matkę, Sina,

Grobstinem okreła

2) Których okrutna Swedow

Srogość wraz pobiła

3) Stego mieysca do Boga

Pragnę by powstali

4) Dla którego Imienia

Krew społem przelali

Czitelniku ty, który czitasz

Prosiemy Cie o pozdrowienie

$\mathrm{Na}[y]$ swietszy Panny

Za nas zmarłych

Sa zabici tirańsko przez okrutne Swedi Dnia 7 M[iesia]ca Kwietnia Roku Pańskiego $1657^{47}$

${ }^{\mathrm{n}}$ Litera „c" nadpisana nad wierszem.

${ }^{42}$ O Annie Krzelczyckiej (zm. 1657), posesorce Węgleszyna, wzmiankuje A. B oniecki, op. cit., t. XII, Warszawa 1908, s. 399.

${ }^{43}$ Polanowice - wieś niedaleko Słomnik w dawnym pow. miechowskim.

${ }^{44}$ O Stanisławie Krzelczyckim por. A. Boniecki, op. cit., t. XII, s. 399; M. Rawita-Witanowski, op. cit., s. 305.

${ }^{45}$ Krzelczyce, obecnie Skrzelczyce - wieś w pow. kieleckim, w gminie Pierzchnica.

${ }^{46}$ O Marcinie Krzelczyckim, synu Anny i Stanisława wspomina A. Boniecki, op. cit., t. XII, s. 399.

${ }_{47}$ Tekst inskrypcji podaje także: J. Wiśniewski, op. cit., s. 368; M. Rawita-Witanowski, op. cit., s. 308; Corpus inscriptionum..., nr 181, s. 160. 


\section{Dzwony}

o-I-szy dzwon. Strona zewnętrzna - napisy idą dookoła dzwonu-o

ME FECI·T IA:[ $N]$ SWOBODA ${ }^{48}$. ECCE: CRUCEM: DOMINI: + FUGITE. BOŻE ZMIEUI SIE NAD NAMI DOPOMO:[Z] NAM- PARTES· ADVERSAE. TEN DZWON PRZE:[LANY] R:[OKU] 1845 KOSZTEM Z BYSTRZOWSKICH KOCHANOWSZK.[ICH] ZA STARA·[NIEM] X· IG·[NACEGO] A SKŁAD: SZ:[ANOWANYCH] PARAFİIAN WINCZAKIEWICZ $[A]$ PROB:[OSZCZA $]^{49}$ FELXK·p BUKOWSKİ ${ }^{50}$

r-II-gi dzwon wewnątrz ${ }^{-\mathrm{r}} 51$

$\mathrm{E}[t]$ Verbum Caro.......... ${ }^{\text {s- }}$ dalej litery zamazane ${ }^{-\mathrm{s}} 52$

o-o Fraza na marginesie.

p Błąd kamieniarza lub pisarza, powinno być: „FELIX”.

r-r Tekst na marginesie.

s-s Nadpisane nad wierszem.

${ }^{48}$ Dziełem tego samego ludwisarza jest także dzwon w Krasocinie $\mathrm{z}$ roku 1844, o którym informuje J. Wiśniewski, Historyczny opis kościołów, miast, zabytków i pamiątek $w$ powiecie włoszczowskim, [b.m.] 1932 (reprint: Kielce 2000), s. 101.

49 Ignacy Winczakiewicz (1813-1873) - proboszcz parafii Węgleszyn od 24 X 1840 r., wcześniej wikariusz w Lelowie. Por. ADK, Akta kurialne ogólne. Życiorysy kapłanów 1835-1840, sygn. OP-X/3, k. 181; ibidem, Akta konsystorskie. Status cleri 1847-1929, sygn. OP-X/13, s. 1140-1141.

${ }^{50}$ Feliks Bukowski - skądinąd nieznany. Zabytek ten notuje J. Wiśniews ki, Historyczny opis kościołów, miast, zabytków i pamiątek w Jędrzejowskiem..., s. 371 .

${ }^{51}$ Dzwon ten, o wadze $250 \mathrm{~kg}$, został zarekwirowany przez Austriaków 22 VIII 1916 r. Por. Dziekan dekanatu jędrzejowskiego do Konsystorza Biskupiego w Kielcach, 30 XI 1916, ADK, Akta konsystorskie. Dzwonów zabranie podczas wojny 1831-1922, sygn. OG-10/12, k. 205; ibidem, 243v. O zabytku tym wzmiankuja ks. W. Siarkowski, Dzwony $w$ gubernii kieleckiej (rzecz archeologiczno-historyczna), Warszawa 1878, s. 26 (tam stwierdzenie, że był to dzwon gotycki); oraz J. Wi śn niew ski, op. cit., s. 371. Dodajmy w uzupełnieniu, że jeśli napis nadzwonny faktycznie wykonany został majuskułą lub minuskuła gotycka, jak sugeruje Siarkowski, to instrument można datować najwcześniej na XVI stulecie. Nie jest to bowiem inskrypcja powszechnie powielana w późnym średniowieczu. Por. W. Kowals ki, „Do zmartwychwstania swego za pewnym wodzem Kristusem...”. Staropolskie inskrypcje północno-zachodniej Małopolski, Kielce 2004, s. 107.

${ }^{52}$ Fragment modlitwy Anioł Pański. Dalsza część frazy brzmi: „factum est et habitavit in nobis” („A Słowo stało się ciałem i zamieszkało między nami”). 
Ecce Cru $\mathrm{H}+\mathrm{E}^{\mathrm{t}}$ cem Domini Fugite MARIA ${ }^{\mathrm{u}}$ Partes aduers $[a] \mathrm{e}^{53}$. $\mathrm{BOM}+\mathrm{UB}+\mathrm{AV}+\mathrm{AB}+\mathrm{OA}+$ dookoła dzwonu na zewnątrz u góry.

\author{
ks [iądz $]$ Paweł Jędrychowski ${ }^{54}$ \\ ${ }^{\text {w- }}$ dwa arkusze ${ }^{-w}$
}

\title{
Bibliografia
}

\section{$\dot{Z}_{\text {RÓDEA ARCHIWALNE }}$}

Archiwum Diecezjalne w Kielcach [ADK]

Akta konsystorskie. Dzwonów zabranie podczas wojny 1831-1922, sygn. OG-10/12.

Akta konsystorskie. Opis kościołów dekanatu jędrzejowskiego 1884-1898, sygn. OD-8/3.

Akta konsystorskie. Status cleri 1847-1929, sygn. OP-X/13.

Akta kurialne ogólne. Życiorysy kapłanów 1835-1840, sygn. OP-X/3.

Akta personalia konsystorskie i kurialne. Status cleri 1876-1938, sygn. OP-X/14.

\section{WYDAWNICTWA ŹRÓDEOWE}

Corpus inscriptionum Poloniae, t. I (Województwo kieleckie), red. J. Szymański, z. 1, z. 2 (Jędrzejów i region jędrzejowski), wydała, wstępem i komentarzem opatrzyła B. Trelińska, Kielce 1978.

Niesiecki K., Herbarz polski, t. VI, wyd. J.N. Bobrowicz, Lipsk 1841.

\section{Opracowania}

Boniecki A., Herbarz polski, cz. 1 (Wiadomości historyczno-genealogiczne o rodach szlacheckich), t. II, Warszawa 1900.

Boniecki A., Herbarz polski, cz. 1 (Wiadomości historyczno-genealogiczne o rodach szlacheckich), t. XII, Warszawa 1908.

Borkiewicz S., Linowski Z., Monografia historyczna i gospodarcza powiatu jędrzejowskiego, Kielce 1937.

Instrukcja wydawnicza dla źródeł historycznych od XVI do połowy XIX wieku, red. K. Lepszy, Wrocław 1953.

\footnotetext{
${ }^{\mathrm{t}}$ Następuje znak oznaczajacy skrót. Prawdopodobnie chodzi tu o chrystogram.

u Słowo oddane jako monogram.

w-w Podkreślone.

${ }^{53}$ Zawołanie św. Antoniego: „Oto Krzyż Pański! Ustapcie, wrogowie Jego!”.

${ }^{54}$ Por. przyp. 14.
} 
Katalog zabytków sztuki w Polsce, t. III (Województwo kieleckie), red. J.Z. Łoziński, B. Wolff, z. 3 (Powiat jędrzejowski), oprac. T. Przypkowski, Warszawa 1957.

Kowalski W., „Do zmartwychwstania swego za pewnym wodzem Kristusem...”. Staropolskie inskrypcje pótnocno-zachodniej Małopolski, Kielce 2004.

Kowalski W., Struktura społeczna szlachty i struktura własności $w$ powiecie chęcinskim w sześćdziesiatych latach XVII wieku, [w:] Stefan Czarniecki. Żołnierz - obywatel-polityk, red. W. Kowalski, Kielce 1999, s. 111-158.

Pielas J., Oleśniccy herbu Dębno w XVI-XVII wieku. Studium z dziejów zamożnej szlachty doby nowożytnej, Kielce 2007.

Pielas J., W sąsiedzkim kręgu Mikołaja Reja. Dzieje klucza węgleszyńskiego w XVI wieku, [w:] Mikołaj Rej z Nagłowic. W pięćsetna rocznice urodzin, red. W. Kowalski, Kielce 2005, s. 177-196.

Prokop K.R., Poczet biskupów krakowskich, Kraków 1999.

Rawita-Witanowski M., Dawny powiat chęciński, z ilustracjami prof. J. Olszewskiego, oprac. D. Kalina, Kielce 2001.

Siarkowski W., Dzwony w gubernii kieleckiej (rzecz archeologiczno-historyczna), Warszawa 1878.

Wegleszyn, [w:] Słownik geograficzny Królestwa Polskiego i innych krajów słowiańskich, red. B. Chlebowski, nakł. F. Sulimierskiego i W. Walewskiego, t. XIII, Warszawa 1893, s. 252.

Wiśniewski J., Historyczny opis kościołów, miast, zabytków i pamiątek $w$ Jędrzejowskiem, Marjówka 1930 (reprint: Kielce 2000).

Wiśniewski J., Historyczny opis kościołów, miast, zabytków i pamiątek $w$ powiecie włoszczowskim, [b.m.] 1932 (reprint: Kielce 2000).

\section{Netografia}

https://kielce.fotopolska.eu/973292,foto.html (dostęp: 12 II 2020).

Matgorzata Karkocha

UNIVERSITY OF LODZ

\section{The parish church in Węgleszyn in the light of accounts of the late $19^{\text {th }}$ century}

$\mathrm{T}$ he critical source edition pertains to description of the parish church under name St. Andrew the Apostle in Węgleszyn (Świętokrzyskie Province), found in the Diocesan Archives in Kielce. The document was prepared on the order of the Kielce Consistory, most probably in the 1890s, by the local priest, priest Pawel Jędrychowski. It is valuable because it contains a lot of important information about the parish temple, hitherto omitted in studies, as well as monuments that do not exist today, irretrievably lost at the beginning of the last century (a Gothic bell, a pulpit having a rare apple-form, the wall decorations). The edited source 
text was preceded by an introductory part, which briefly presents the history of the parish and village Wegleszyn, discussed the external and internal appearance of the temple, its decor and equipment.

Keywords: Węgleszyn, parish church, source edition, $19^{\text {th }}$ century.

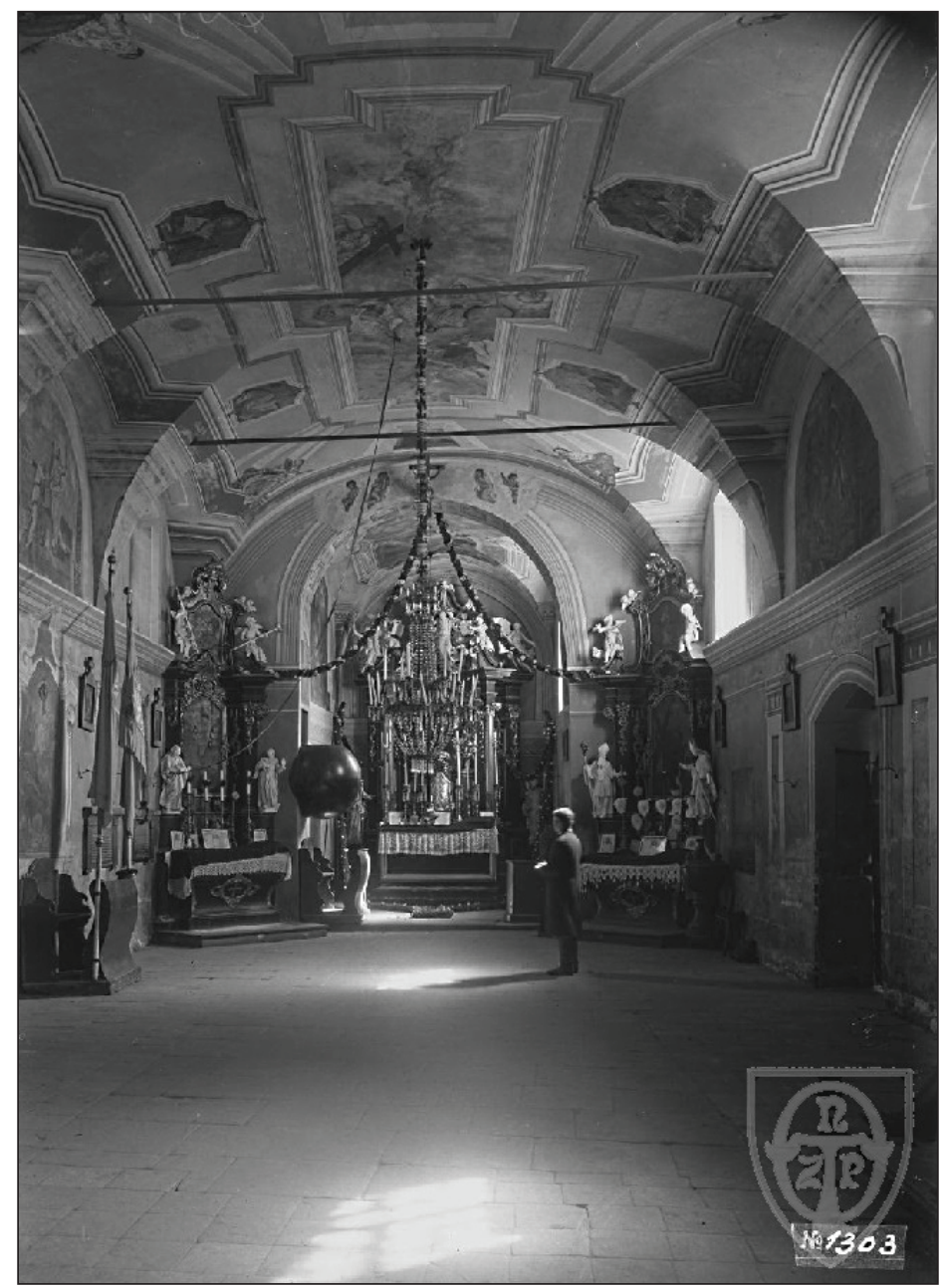

1. Węgleszyn, wnętrze kościoła parafialnego, 1905-1910 Towarzystwo Opieki nad Zabytkami Przeszłości

- https:/ / kielce.fotopolska.eu/foto/973/973290.jpg 


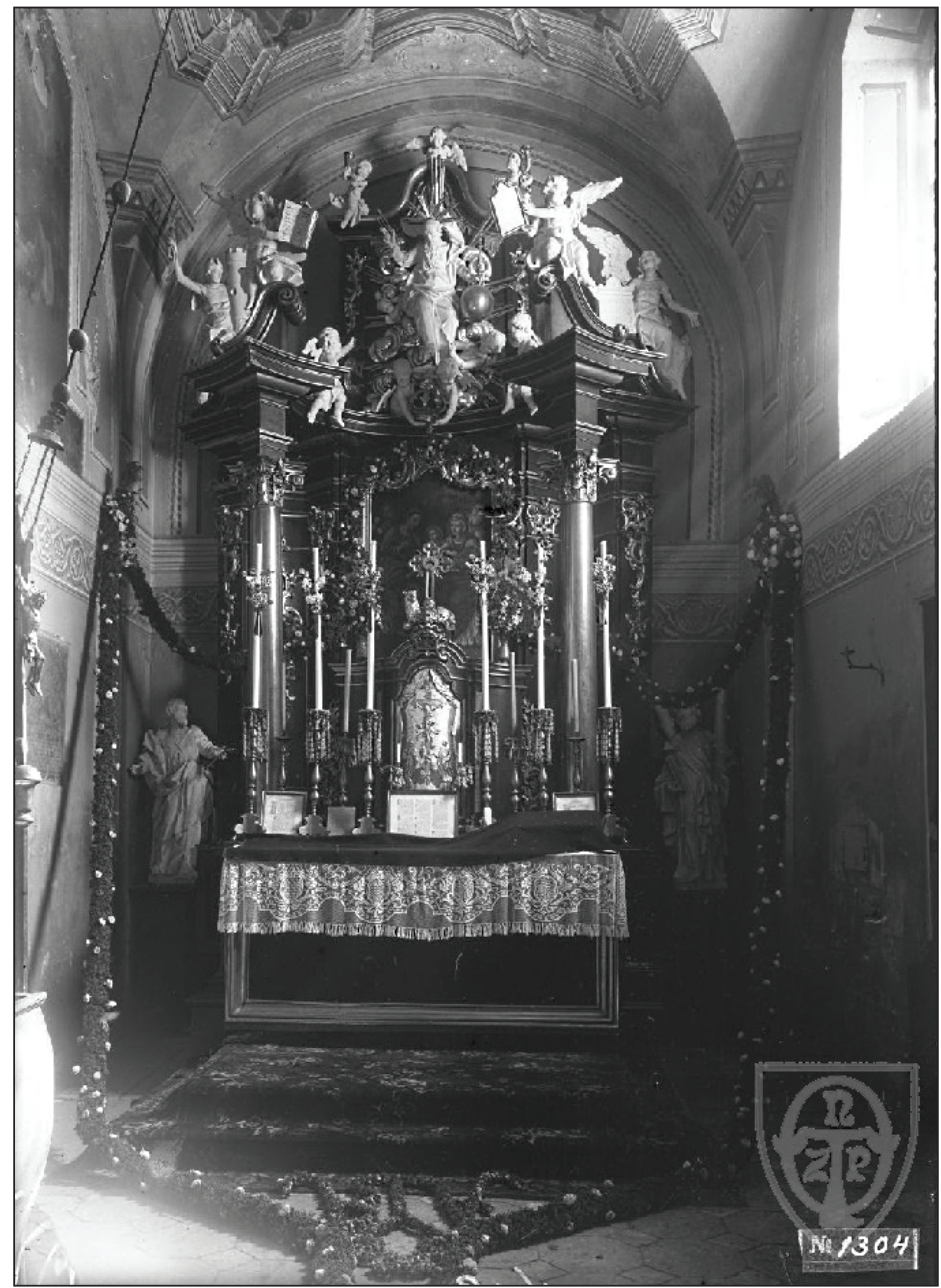

2. Węgleszyn, ołtarz główny, 1905-1910

Towarzystwo Opieki nad Zabytkami Przeszłości

- https://kielce.fotopolska.eu/foto/973/973291.jpg 